\title{
Seismic performance analysis of wedge-shaped Castellated portal frame
}

\author{
Yuxiao Lang ${ }^{1, *}$, Lianguang $\mathrm{Jia}^{1}$ \\ ${ }^{1}$ School of Civil Engineering, Shenyang Jianzhu University,No.9,Hunnan Road, Hunnan District, Shenyang City, Liaoning, P.R. China
}

\begin{abstract}
In order to study the seismic performance of wedge-shaped light steel castellated portal frame, the finite element analysis software Abaqus is used to simulate the seismic behavior of the portal frame with a single span hexagonal hole with a span of $24 \mathrm{~m}$. The influence of the opening ratio and the distance between the first hole of the near column and the end to the column edge on the hysteretic curve, skeleton curve, stiffness degeneration, ductility and energy dissipation capability are analyzed and the ultimate destructive form is also obtained. The results show that under the low cycle reciprocating load, the castellated light steel portal frame forms the plastic hinge on both sides of the structure near the first hole, and the structure loses its carrying capacity. The greater the opening ratio is, the lower the ultimate bearing capacity is, and the stiffness degeneration is more notable, ductility and energy dissipation are worse. The distance between the first hole of the near column and the end to the column edge has great influence on the ultimate bearing capacity, stiffness degradation and ductility. The greater the distance is, the better the ultimate bearing capacity and the ductility are.
\end{abstract}

\section{Introduction}

With the development of economy, the concept of green building is getting more and more popular. Light steel structure, as an important symbol of low-carbon environmental protection, has been widely used in the supermarket, civil buildings, sports venues and other buildings. Portal frame structure is a commonly used structural form ${ }^{[1]}$. According to the mechanical characteristics of portal frame structure, the member is designed into wedge shape, which satisfies the force of the structure and saves the material ${ }^{[2-4]}$.

Castellated steel members have advantages of bending stiffness and remarkable economic benefit ${ }^{[-7]}$. Wedgeshaped castellated members have the common advantages of wedge-shaped members and castellated beams. They are applied in portal frame structure, which is not only beautiful in appearance but also convenient for layout of equipment and pipelines, and has good application prospect.

At present, some scholars have made some achievements in the research on the mechanical properties and seismic behavior of castellated steel frame ${ }^{[8]}$. But the research of the equivalent section castellated light steel portal frame is only in the initial stage, and the long-span portal frame structure often uses the wedge-shaped section. This paper will use the finite element analysis software Abaqus to analysis the seismic performance of a single span hexagonal hole wedge-shaped beam portal frame with a span of $24 \mathrm{~m}$. The influence of the opening ratio and the distance of the first hole to the column edge on the seismic behavior of the structure is analyzed, which provides reference for the design and application of the castellated light steel portal frame.

\section{Finite Element Analysis model}

\subsection{Model design}

The single span hexagonal hole wedge-shaped beam portal frame with a span of $24 \mathrm{~m}$ is designed. The slope is $1: 15$, the height of the cornice is $6.9 \mathrm{~m}$, and the hinge pin is used. The cross-section dimensions of the rigid frame are shown in table 1 .

Table1. Sectional dimensions of castellated beam portal frame

\begin{tabular}{|c|c|c|c|c|}
\hline $\begin{array}{c}\text { Dimension } \\
\text { parameter } \\
(\mathrm{mm})\end{array}$ & $\begin{array}{c}\text { The } \\
\text { bottom } \\
\text { of the } \\
\text { column }\end{array}$ & $\begin{array}{c}\text { The top } \\
\text { of the } \\
\text { column }\end{array}$ & $\begin{array}{c}\text { Beam } \\
\text { end } \\
\text { section }\end{array}$ & $\begin{array}{c}\text { Beam cross } \\
\text { section }\end{array}$ \\
\hline $\begin{array}{c}\text { Depth of } \\
\text { section }\end{array}$ & 300 & 700 & 858 & 390 \\
\hline Flange width & 240 & 240 & 180 & 180 \\
\hline $\begin{array}{c}\text { Flange } \\
\text { thickness }\end{array}$ & 8 & 8 & 6 & 6 \\
\hline $\begin{array}{c}\text { Web } \\
\text { thickness }\end{array}$ & 6 & 6 & 5 & 5 \\
\hline
\end{tabular}

The specimen number is named in the form of a beam, such as a model named "2460-h", in which "24" represents a span of $24 \mathrm{~m}, " 60$ " represents the opening ratio of the castellated beam as "h2/h1 $=60 \%$ ", and " $\mathrm{H}$ " represents the distance of the first hole of the rigid frame to the column edge as " $\mathrm{S}=1 \mathrm{H}$ ", the parameters are shown in Table 2 and Figure 1 .

* Corresponding author: Yuxiao Lang: 1254956227@qq.com 
Table2. Dimensional parameters of castellated portal frame

\begin{tabular}{|c|c|c|c|c|}
\hline $\begin{array}{c}\text { Specimen } \\
\text { number }\end{array}$ & $\begin{array}{c}\text { Opening } \\
\text { ratio } \mathrm{h}_{2} / \mathrm{h}_{1}\end{array}$ & $\begin{array}{c}\text { The } \\
\text { distance of } \\
\text { the first } \\
\text { hole S/mm }\end{array}$ & $\begin{array}{c}\text { The first } \\
\text { hole side } \\
\text { length } \\
\mathrm{L} / \mathrm{mm}\end{array}$ & $\begin{array}{c}\text { Hole } \\
\text { pitch } \\
\mathrm{d} / \mathrm{mm}\end{array}$ \\
\hline $2450-\mathrm{H}$ & $50 \%$ & 858 & 230.0 & 363 \\
\hline $2455-\mathrm{H}$ & $55 \%$ & 858 & 254.0 & 400 \\
\hline $2460-0.5 \mathrm{H}$ & $60 \%$ & 429 & 284 & 404 \\
\hline $2460-\mathrm{H}$ & $60 \%$ & 858 & 278 & 374 \\
\hline $2460-1.5 \mathrm{H}$ & $60 \%$ & 1287 & 270 & 414 \\
\hline $2460-2 \mathrm{H}$ & $60 \%$ & 1716 & 278 & 370 \\
\hline $2465-\mathrm{H}$ & $65 \%$ & 858 & 300 & 415 \\
\hline $2470-\mathrm{H}$ & $70 \%$ & 858 & 324 & 382 \\
\hline
\end{tabular}

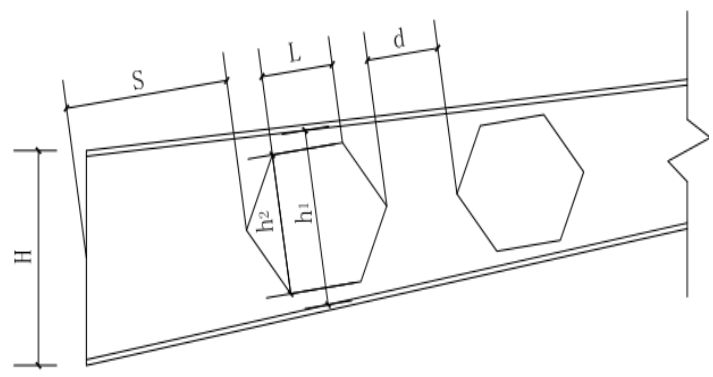

Figure 1. Size parameter of castellated beam

\subsection{Material parameters and unit selection}

In the finite element model of the wedge-shaped section portal frame structure, the steel grades of each member are Q235B, the elastic modulus is $2.06 \times 105 \mathrm{Mpa}$, Poisson's ratio is 0.3 . The constitutive model of steel uses double slash model, and strengthen section modulus take 0.01 times of elastic modulus. The unit type uses C3D8R (eight connections six plane) linear reduction integral element, and the rigid frame connection all uses the welding.

\subsection{Loading method}

Vertical load: Roof constant load is $0.25 \mathrm{kN} / \mathrm{m}^{2}$, roof live load is $0.5 \mathrm{kN} / \mathrm{m}^{2}$, and column distance is $6 \mathrm{~m}$, the load action mode shown in Figure 2. First, put the monotonic static loading on the structure, the yield displacement of the cellular beam portal frame under horizontal load is carried out, and then the low cycle reciprocating loading process is given. When the structure enters yielding, on the basis of yielding displacement, each level of displacement load increases $5 \mathrm{~mm}$, and each load cycle for one time, until the structure is destroyed.

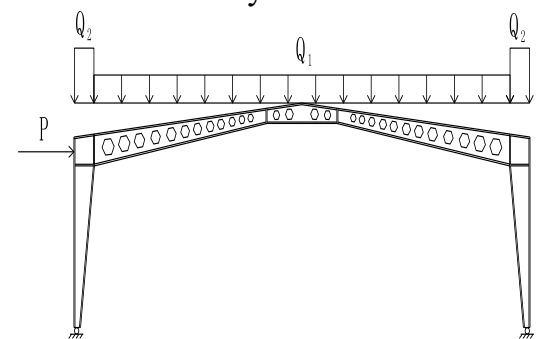

Figure 2. Model loading diagram

\section{Simulation results analysis}

\subsection{Failure mode}

The results of finite element analysis show that under the action of low cycle reciprocating load, the internal force change and the final failure form of the castellated beam portal frame under different parameters are similar. Taking rigid frame $2460-\mathrm{H}$ as an example, with the increase of the amplitude of the horizontal displacement load, the lower flange of the beam at the first hole is first entered into yielding, and as the amplitude of the displacement load increases, the upper flange near the cross section is entered into the yielding. Finally the local buckling is produced by the two holes entering the full cross section yielding, two plastic hinges are formed. The rigid frame beams have obvious collapse under vertical load. The whole structure loses the ability to continue to withstand horizontal loads.

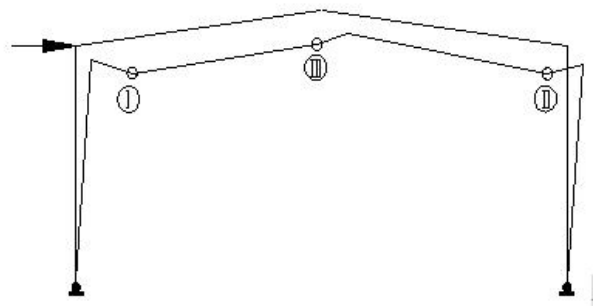

Figure 3. Failure mode analysis of castellated beam portal frame

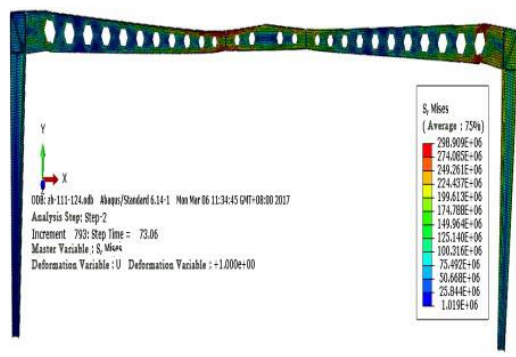

Figure 4. Stress cloud of the broken castellated portal frame

\subsection{Hysteresis curve}

Hysteretic curve is the main basis for evaluating seismic performance of structures, and the hysteretic curves of each specimen are shown in figure 5. In the initial stage of displacement loading, the structure is in elastic phase, the hysteretic curves of each specimen are close to the coincident oblique line. After loading to the yield displacement, the horizontal section is present in the hysteretic curve of each specimen, the lower flange section of the beam at the first hole of the near-end is entered into yielding, it shows a fuller spindle and the cyclic loading continues. The ability of the structure to withstand the horizontal load decreases greatly and the structure loses the load capacity when the first hole of the beam yielded. 


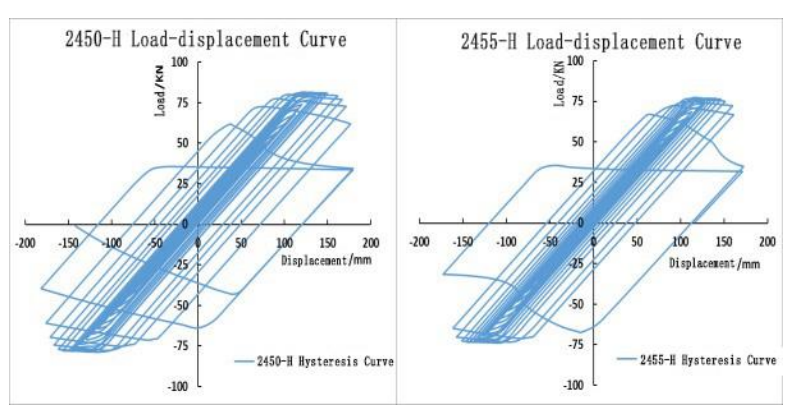

(a) $2450-\mathrm{H}$

(b) $2455-\mathrm{H}$

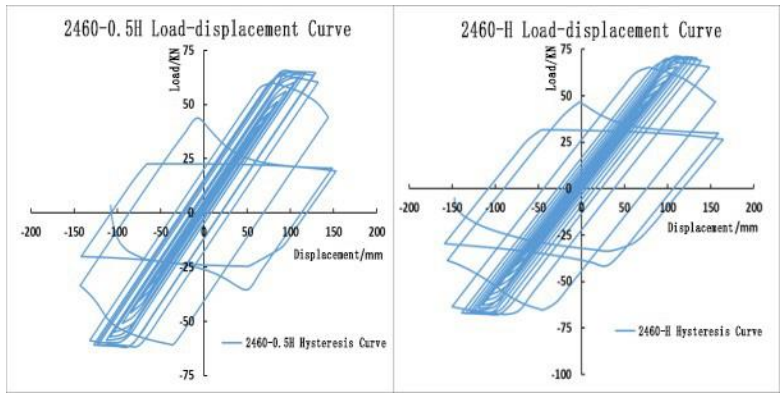

(c) $2460-0.5 \mathrm{H}$

(d) $2460-\mathrm{H}$

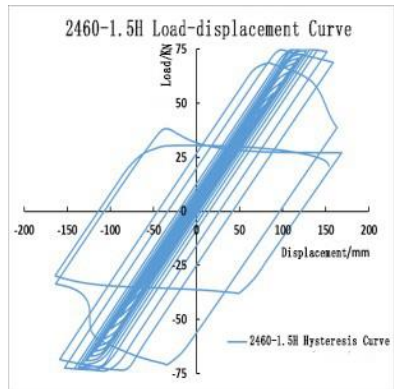

(e) $2460-1.5 \mathrm{H}$

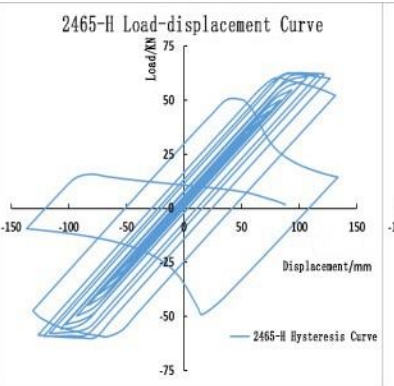

(g) $2465-\mathrm{H}$

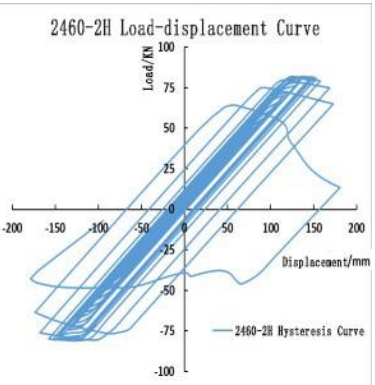

(f) $2460-2 \mathrm{H}$

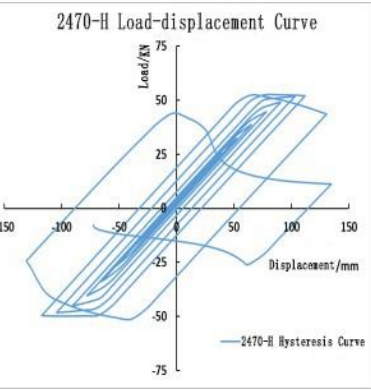

(h) $2470-\mathrm{H}$
Figure 5. Hysteretic curve of castellated beam portal frame

\subsection{Skeleton curve}

The skeleton curve of the castellated portal frame with different parameters is shown in figure 6 (a) (b). At the beginning of loading, the skeleton curves of each specimen are straight lines and the structure is in an elastic stage. When the structure enters the plastic stage, the skeleton curve begins to diverge, reaches their peak load and then drops precipitously. It can be seen that the higher the opening ratio is, the lower the bearing capacity (peak load) of the structure is. The greater the distance from the first hole to the column edge of the near column beam is, the higher the bearing capacity of the structure is.

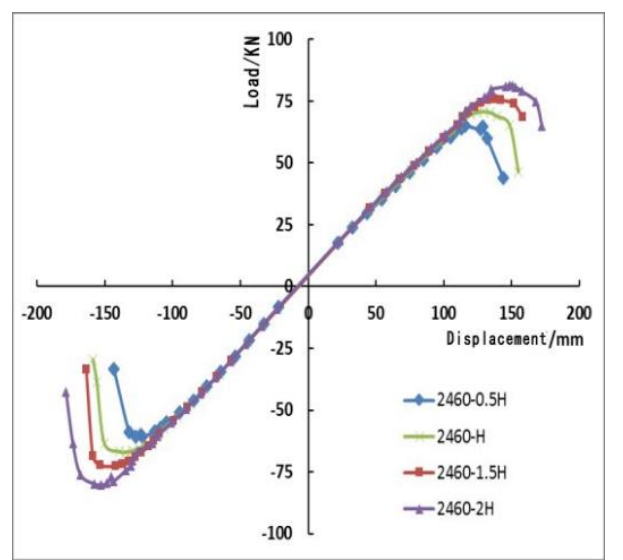

(a) The frame skeleton curve of different distance

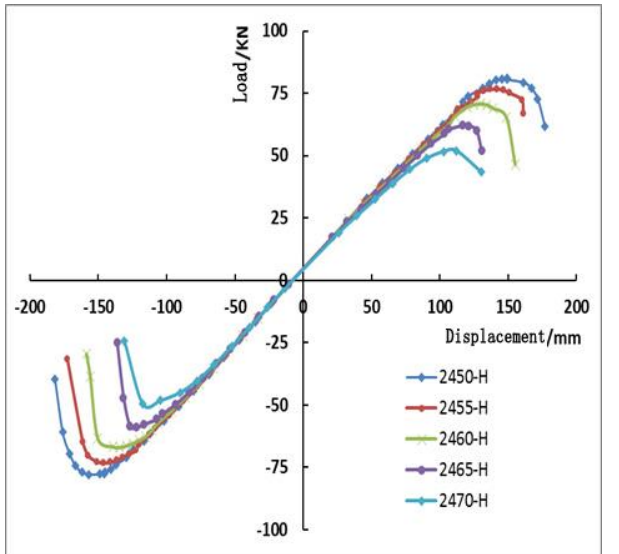

(b) Skeleton curves with different openings ratio

Figure 6. Comparison of skeleton curves

\subsection{Stiffness degradation}

Figure 7 (a) (b) gives the stiffness curves of each specimen, the opening ratio has a greater influence on the stiffness at the initial loading stage, and that the distance between the first hole and the column edge at the end of the near column has a small effect. After the structure enters the plastic stage, all specimens have obvious stiffness degeneration. The smaller the distance is, the more obvious the stiffness degeneration is.

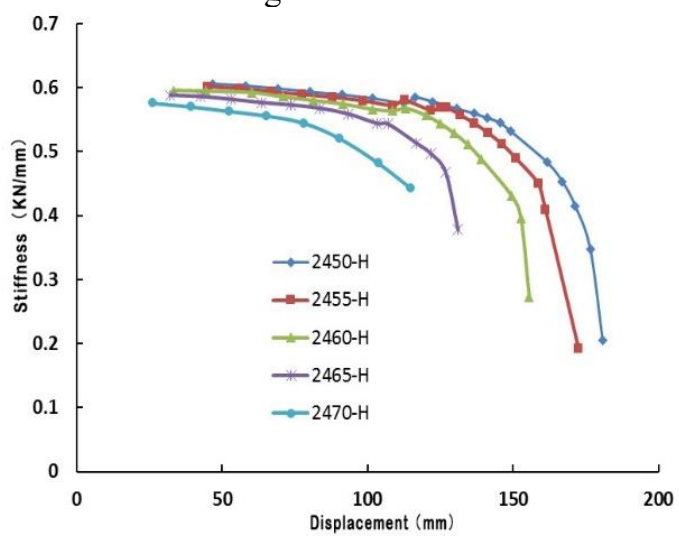

(a) Stiffness degradation curve with different openings ratio 


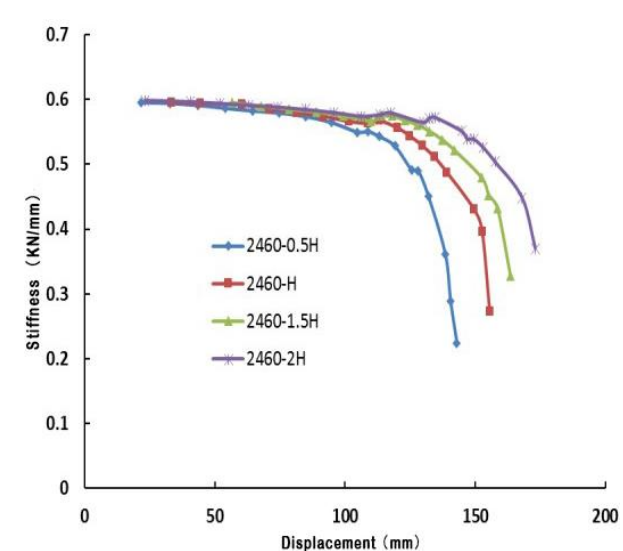

(b) Stiffness degradation curve of different distance

Figure 7. Comparison of stiffness curves of frames

\subsection{Ductility}

Table 3 gives the relative data of the displacement ductility coefficient of the finite element simulation, it can be seen that the higher the opening ratio is, the earlier the structure enters yield and the ductility performance is improved. The greater the distance between the first hole and the edge of the column is, the higher the ductility performance is.

\subsection{Energy dissipation capacity}

The equivalent viscous damping coefficient $h_{\varepsilon}$ and energy dissipation coefficient $E$ are used to express the energy dissipation capacity of the specimen ${ }^{[9]}$. The equivalent viscous damping coefficient $h_{\varepsilon}$ and energy dissipation

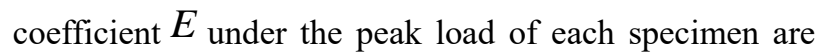
given in table 4 . With the increase of opening ratio, the section of the castellated hole which forms the plastic hinge decreases gradually, and the energy dissipation is gradually weakened. The distance between the first hole and the column edge of the near column has little influence on the energy dissipation ability of the whole structure.

Table3. The ductility coefficient of frames

\begin{tabular}{|c|c|c|c|}
\hline $\begin{array}{c}\text { Model } \\
\text { number }\end{array}$ & $\begin{array}{c}\text { Yield } \\
\text { displaceme } \\
\text { nt } / \mathrm{mm}\end{array}$ & $\begin{array}{c}\text { Limit } \\
\text { displacement } \\
/ \mathrm{mm}\end{array}$ & $\begin{array}{c}\text { Ductility } \\
\text { factor }\end{array}$ \\
\hline $2450-\mathrm{H}$ & 117 & 165.53 & 1.41 \\
\hline $2455-\mathrm{H}$ & 113 & 161.59 & 1.43 \\
\hline $\begin{array}{c}2460- \\
0.5 \mathrm{H}\end{array}$ & 109 & 140.16 & 1.29 \\
\hline $2460-\mathrm{H}$ & 111 & 159.96 & 1.44 \\
\hline $2460-$ & 113 & 163.88 & 1.45 \\
\hline $1.5 \mathrm{H}$ & 116 & 170.52 & 1.47 \\
\hline $2460-2 \mathrm{H}$ & 99 & 145.54 & 1.47 \\
\hline $2465-\mathrm{H}$ & 85 & 128.35 & 1.51 \\
\hline $2470-\mathrm{H}$ & & &
\end{tabular}

Table4. The peak load energy dissipation coefficient of each frame

\begin{tabular}{|c|c|c|}
\hline Model number & $h_{\varepsilon}$ & $E$ \\
\hline $2450-\mathrm{H}$ & 0.293 & 1.841 \\
\hline $2455-\mathrm{H}$ & 0.237 & 1.488 \\
\hline $2460-0.5 \mathrm{H}$ & 0.203 & 1.275 \\
\hline $2460-\mathrm{H}$ & 0.206 & 1.295 \\
\hline $2460-1.5 \mathrm{H}$ & 0.201 & 1.262 \\
\hline $2460-2 \mathrm{H}$ & 0.209 & 1.314 \\
\hline $2465-\mathrm{H}$ & 0.193 & 1.215 \\
\hline $2470-\mathrm{H}$ & 0.178 & 1.118 \\
\hline
\end{tabular}

\section{Conclusion}

(1)Under the action of low cycle reciprocating load, castellated light steel portal frame has plastic hinge on both sides of the structure near the first hole. When the plastic hinge enters the full cross section, the rigid frame oblique beam has a large vertical displacement and the structure loses its carrying capacity.

(2) The opening ratio of the portal frame has great influence on the seismic performance. The higher the opening ratio is, the lower the ultimate bearing capacity is, the more obvious the stiffness degradation is. When the opening ratio is large, the damage occurs at the hole position. The specimen still has high bearing capacity and the ductility is relatively good after the peak load.

(3) Under horizontal load, the influence of distance for ultimate bearing capacity, stiffness degradation and ductility is relatively large, the influence on the overall energy dissipation capacity is relatively small. The greater the distance is, the better the ultimate bearing capacity and the ductility are. After the structure enters the plastic stage, the smaller the distance is, the more obvious the stiffness degeneration is.

\section{References}

1. A. Mohebkhah, H. Showkati. Bracing requirements for inelastic castellated beams. J. Journal of Constructional Steel Research, 61(10):1373-1386 (2005)

2. Y.S. Shao, H.B. Liu, L.L. Xie. Research on static behavior of wedge-shaped honeycomb I-beam bending member. $\mathrm{J}(2008)$

3. Y.L. Guo, W.M. Wang, Y.J. Shi. Nonlinear performance of variable-section portal frame structures. J. Engineering Mechanics, 17 (4): 2936(2007)

4. N. Yang, S.Z. Shen. Study on geometrical nonlinearity of portal frame with variable crosssection. J. Journal of Harbin Institute of Technology, 34 (3): 10-15(2001)

5. M.R. Soltani, A. Bouchaïr, M. Mimoune. Nonlinear FE analysis of the ultimate behavior of steel castellated beams. J. Journal of Constructional Steel Research, 70(2):101-114(2012)

6. T.C.H. Liu, K.F. Chung. Steel beams with large web 
openings of various shapes and sizes: finite element investigation. J. Journal of Constructional Steel Research, 59(9):1159-1176 (2003)

7. P.F. Li, Q.F. Yao, M. Guo. Torsional buckling analysis of honeycomb flexural and calculation method of global stability. J. Journal of Beijing Jiaotong University, 34 (4): 60-64(2010)

8. L.G Jia, H.D. Sun, C.G. Wang. Experimental study on seismic behavior of honeycomb steel frame structure. J. Engineering Mechanics, 29 (7): 147-153(2012)

9. AISC 341-05 Seismic provisions for structural steel buildings. S. American Institute of Steel Construction, INC., March 9(2005) 